\title{
8 \\ Learning to Become a Geographer: Reproduction and Transformation in Academia
}

\author{
Harald Bauder
}

2006. Antipode 38 (4), 671-79 1

[T]he institution recognizes those who recognize it.

- Pierre Bourdieu $(1988,101)$

\section{Introduction}

Academic socialization begins with undergraduate and graduate education. While incoming graduate students in North American geography programs may expect that their program will teach them geographic knowledge and scientific truths, few students probably anticipate that a great deal of their program involves learning how to perform the social and cultural roles expected of academic geographers. By the time academic geographers assume faculty positions, romanticized ideas of being a knowledge-seeking scholar or Gramscian-style intellectual who changes the world may have been dashed by the realities of academic practice.

Educational institutions have always been sites where young people assume the roles of "unconscious foot soldiers" (Willis, 2003, 390) in the production and reproduction of society. In the case of graduate students and early-career faculty in postsecondary geography, their socialization serves the reproduction of academic geography itself. The realization that academia is a self-reproducing institution is nothing new, of course. Many books have been written about academic labor and

\footnotetext{
${ }^{1}$ Reprinted with permission from Wiley-Blackwell Publishing Ltd.
} 
reproduction (e.g. Becher, 1989; Gouldner, 1979; Halsey and Tow, 1971; Said, 1994). The inaugural editorial in Antipode critiqued institutions, academia in particular, "that often serve no purpose than perpetuating themselves (Stea, 1969, 1)." Yet, more than 30 years later, Susan Roberts observed: "Indeed, many times, the means, for faculty as well as students, seem to have become the ends (Roberts, 2000, 236, original emphasis)." Most of us continue to comply with everyday conventions and uncritically embrace both established and new academic practices that reproduce the university and enable it to pursue its current path of corporatization (Mitchell, 1999; Smith, 2000). The persistence of questionable practices of self-reproduction is precisely why we must intervene today. Recent research and professional initiatives have pointed out the anxieties and concerns among junior faculty that have arisen from professional socialization with the goal of easing their transition from graduate student to faculty member (Geography Faculty Development Alliance, 2005; Solem and Foote, 2005). However, rather than merely encouraging quick and smooth socialization of students and new faculty, we, the geographic community, must engage critically with processes of reproduction and create the spaces in which problematic professional practices can be challenged and transformed.

The audiences I have in mind for this intervention are not only faculty but also graduate students. In my department, I have taught the Ph.D. course "Geographic Scholarship and Research." [In the Fall 2005 term], I decided to make "professional development" a key focus in the course. My own experience as recently tenured academic geographer is that professional skills and knowledge about the nature of academic work are essential for a successful entrance into an academic career. However, my course entailed not only teaching practical knowledge of academic practice but, more importantly, sought to unveil the underlying processes of institutional reproduction that structure our academic world. In this [essay] I seek to examine some of the forces of reproduction that are not always apparent to students and faculty deeply absorbed in everyday academic life.

\section{Academia as Social Field}

While the institution of the university may formally enable scientific research, facilitate social critique and embrace the spirit of intellectual freedom, it also defines the parameters of academic practice within which these activities are supposed to occur. These parameters include attracting increasing amounts of grant money, pursuing knowledge transfer to the state and/or private sectors, teaching "practical" knowledge attractive to employers, working excessive hours, and publishing in large volumes and in highly-rated journals. Our publication conventions and expectations, for example, often comply with and facilitate the corporatization of our community. When the participants of the "Beyond the Academy? Critical Geographies in Action?" conference sought a publishing outlet for their papers, the "vast majority favoured 
publication in the Antipode book series (with REA and tenure issues being a predominant factor in a number of contributors minds)" (Fuller and Kitchin, 2004, 910). Only after the publisher, Blackwell Publishing, Inc., declined due to a lack of "commercial viability (Fuller and Kitchin, 2004, 10)" did the group opt for a noncommercial publisher, Praxis (e)Press. Due to this switch in publishers, some contributors withdrew their chapters. Similar to non-corporate presses, non-corporate journals, such as $A C M E$, are struggling to establish reputations among academics that can match that of their corporate counterparts.

Other academic practices are also implicated in processes of capitalization, including activism and the pursuit of grant money. Numerous publications exist in which academic geographers address their difficulties of engaging in activism (e.g. Blomley, 1994; Duncan and Fuller 2004; Tickel, 1995). A problem, in my view, is that our peer-assessment conventions typically attribute greater value to attracting large sums of grant money (or to accumulating publications) than to spending large numbers of hours on activist work. The department in which I work, for example, is proud to regularly outcompete other departments in our college in respect to grant money, while faculty activist involvement typically goes unmentioned.

Of course, self-critique is not absent from academia. In geography, there have been long-standing debates about activism in academia (Blomley, 1994; Fuller and Kitchen, 2004; Tickel, 1995;), the privatization of the university (Castree and Sparke, 2000; Mitchell, 1999; Smith, 2000) and the discipline's role in society (Castree, 2000; Castree and Wright, 2005; Ward, 2005). While much of this critique focuses on our engagement with the world "out there," increasing attention has also been paid to the "in here" and our own academic practices (Castree, 1999, 2000). In this respect, David Stea $(1969,1)$ critiqued the academic incorporation of "economic values;" Jane Willis (1996, 294) lamented how our own labor practices "are squeezing [the] 'substance' from the lives of academics;" Noel Castree (1999, 84) suggested focussing our activism on "the academic sweatshop;" and Pamela Moss, Lawrence Berg and Caroline Desbiens (2002) outlined an agenda for non-corporate publishing. However, rarely do we address the reproduction of academic practices and conventions through our own everyday behaviour and interaction with students and colleagues. We rarely ask how and why we convey "the nature" of academic work to our students. While feminist geographers have attempted over the last twenty years to rescript some of the conventions that reproduce gender inequalities in academia, other questionable social and cultural practices continue unquestioned. We need, in my view, not only the collective will but also self-critical and self-reflective insights to resist and transform processes of reproduction.

Why do North American geographers seem to play a "game of self-deceit" (Bourdieu, 1988, 19) regarding their own reproduction? The answer, I think, is that we have been socialized into practices that we use to define our professional identity. More precisely, academia defines a social field with "its own logic (Bourdieu, 1988, 53)," which differs from that of, say, the business world or politics. One way of 
thinking about the academic field and its practices is through habitus, which describes a system of behaviour and thought shared among the members of a social group (Bourdieu, 1977, 2002). Anglo-American academic geographers "possess a set of specific (though complex and nonunified) class habituses which arise in part from their professional status ... they dance, if you like, to the same institutional tune" (Castree, 2000, 962). Through continued exposure to academic geography and the reinforcement of its norms and values, this academic habitus is naturalized. A less jargon-laden way to think about the academic field is as a game. Academics need to be willing and able to play by the rules of the game if they want to be included as members of the institution. The sustainability of our professional identity relies on the continuation of the game and its rules.

Reproduction also solidifies existing hierarchies and configurations of prestige within academia. For example, by conveying to students and junior colleagues that publishing and attracting grant money signifies academic achievement, well-published and funded senior faculty are able to congeal their status as accomplished academics. The problem is that once we are trying to out-publish and out-fund each other, we find it more difficult to pursue collective aims, such as improving our working conditions (Willis, 1996), resisting our absorption by corporate interests (Mitchell, 1999; Smith, 2000) or changing the rules of the game in the first place. In fact, the principle of competition is an increasingly dominant rule at Anglo-American universities, as evidenced by research assessment procedures in the U.K. and promotion and tenure evaluations in North America. In this respect there are signs of convergence between US and UK university systems (Castree, 1999, 2000; Castree and Sparke, 2000; Sidaway, 1997).

\section{Reproduction and Transformation at Early-Career}

The people at the helm of the academic field (senior university administrators, officers of professional organizations, journal editors, chairs, professors, etc.) have already made large investments into the game of academia and therefore have an interest in maintaining its rules and practices. When supervising and mentoring faculty guide students and junior colleagues through the socialization process, they solidify their own position. "Patronage is power," say Johnston and Sidaway (2004, 38). Graduate programs and non-tenured junior positions are essential to initiate new generations of academics into the academic game and constitute a critical infrastructure for the reproduction of the academic field.

Reproduction begins with the selection of suitable undergraduate students, especially those who show potential to conform and submit to academic practices. The indicators we use to assess the potential of successful socialization are listed on the graduate program application forms and typically include a record of past academic 
performance and the judgments of our colleagues in the form of recommendation letters. Once students are accepted, our graduate programs teach them the cultural competence to "perform" geography (Smith, 2000). "[W]hat teaching must transmit or reinforce ... is not knowledge, not a package of scientific knowledge, but skill or, more exactly, the art of applying knowledge, and applying it aptly in practice, which is inseparable from an overall manner of acting, or living, inseparable from a habitus (Bourdieu, 1988, 57, original emphasis)." Incoming graduate students may wonder not only about our convoluted writing styles, but also about peculiar expectations of publishing, seeking funding or pursuing applied research. Our graduate programs expose students to these practices. The incentive to conform is the prospect of a doctorate degree. A time-limited teaching position can be seen as an "apprenticeship" (Johnston and Sidaway, 2004, 32) during which socialization into the academic habitus continues. By the time geographers receive tenure at a university, they will have internalized "proper" academic styles and conventions, accepting them as normal.

A recent essay by Michael Solem and Kenneth Foote (2004) reveals some of the strategies of socialization to which early-career faculty in North American geography departments are exposed. The article describes the results of a survey of attitudes towards "academic culture (908)" and anxieties arising from "academic socialization (908)." "[M]entoring from senior colleagues in the department," "advice from faculty at other institutions," "networking with peers," and "seeking help from department chair" are all strategies that help new faculty members in "getting to know local academic culture" (Solem and Foote, 2004, 897). Similarly, "mentoring seems to have cultivated appreciation for the nature of faculty work... (900, my emphasis)," or, "lackluster performance can be linked to faculty members' misunderstanding of performance expectations and/or their failure early on to interact constructively with peers and senior colleagues (904)." New faculty who receive mentoring from colleagues and counseling from department chairs and who develop professional networks tap "into the tacit knowledge of seasoned faculty (906)," and are therefore more likely to succeed in the academic game, measured by promotion and other performance standards. The essay illustrates how social reproduction in academic geography works through the language of professional development and well-intended assistance to early-career academics, socializing new faculty members into academia's habitus, and thus providing the conditions for "successful and satisfying academic careers (Solem and Foote, 2004, 889)."

Increasingly, our didactical strategy of student socialization involves learningby-doing. "(W)e suggest (students) do everything faculty members are supposed to do (Roberts, 2000, 236)." We encourage them to accumulate peer-reviewed publications, apply for grants and work excessive hours. The initiation process into academic practice is continued through postdoctoral work and non-tenured faculty positions. The competition principle demands that students, postdocs and early-career faculty comply with these practices, or be punished (or at least threatened) with dismissal from the academic community. 
This strategy relies on unequal power relationships between supervisors and graduate students. At North American universities, where I completed graduate and postdoctoral work and where I work now as a tenured faculty member, subtle everyday practices continuously remind students of their lower rank and apprentice status. They are expected to knock humbly on professors' doors and patiently wait their turn to speak, while the professors typically walk right into the student's offices and immediately demand undivided attention. Graduate students are given a sense that they move up in the pecking order by being offered to address professors by their first name, distinguishing them from undergraduate students who are denied this privilege. Mentoring of junior faculty by their senior colleagues relies on similarly unequal power relationships (Hardwick, 2005).

Another important element in the reproduction of the academic field is the valorization of the field itself. For many students and early-early career faculty, to be an academic geographer also means prioritizing their careers relative to their families, friends and hobbies (Roberts, 2000). In Solem and Foote's (2004, 894) interview sample, a respondent laments that "in academics in general there is not enough sensitivity to the personal demands that people have." Many of my own fellow graduate students and postdoctoral peers sacrificed their romantic relationships to pursue junior faculty positions in different cities or countries. By valorizing the academic field we endorse its practices. Having made such sacrifices for our careers, many of us are reluctant to challenge the norms and conventions that enabled these careers.

The transformation of the academic field can be initiated by external processes, such as corporatism and neoliberalism that currently penetrate academia, or by internal forces, as exemplified by feminist interventions to make the discipline more gender equitable. Senior administrators, journal editors and established professors have significant means to shape the field from the inside. They control appointments, define publishing conventions, and shape faculty assessment and tenure procedures. They can summon institutional resources - such as the program Enhancing Departments and Graduate Education (EDGE), funded by the US National Science Foundation and administered by the Association of American Geographers, which seeks to sensitize graduate education "to the experiences of women, ethnic minority, gay, and foreign students who often become marginalized in traditional academic environments (AAG, 2005)." Other established academics attempt to "shift the politics of the field (Mitchell, 2002)" through writing, teaching and other interventions. Yet, these seasoned academics also have the greatest interest in maintaining practices that endow them with power and prestige.

Junior faculty and graduate students, on the other hand, may have greater reason to contest, disrupt and transform practices that instigate destructive competition, facilitate the corporatization of academia and diminish workplace satisfaction. Thomas Kuhn (1969) once suggested that junior scientists who have previously invested little 
in the dominant scientific paradigm are more likely to endorse new paradigms. In a similar way, graduate students and early-career faculty who have not yet invested decades of their careers into existing academic conventions are important potential agents in the transformation of the academic field. Despite this potential, however, they are in vulnerable positions, experience intense pressure to conform to existing conventions and practices, and are structurally least well positioned to facilitate change.

The dilemma thus is that those endowed with the capacity to initiate change have an interest in institutional reproduction, while those with an inclination for transformation typically lack the institutional authority and political resources to produce significant change. To overcome this dilemma, we - students, junior faculty and senior academics - must act collectively. First, we must recognize our own roles in reproducing academic geography and the implications of our everyday practices. Seasoned academics should see graduate students and early career faculty as agents for change, rather than instruments of reproduction, and encourage them to scrutinize established institutional practices and conventions. As radical and critical geographers, we should strive towards Antipode's aims, stated on the journal's homepage, "to challenge dominant and orthodox views of the world ..., creating new spaces and envisioning new futures." Focusing on our own taken-for-granted world would move us towards this aim.

Second, established academics can help create the spaces in which to discuss processes of academic reproduction and identify the purposes these processes serve. Journals such as Antipode, graduate courses and junior faculty mentoring programs are important forums in which these discussions should take place. Faculty and student unions could play a role in writing new practices into collective agreements. These spaces can serve as a catalyst by which we collectively transform problematic conventions.

Through enlightened debate, I believe it is possible to change problematic conventions. For example, after publishing their book with Praxis (e)Press, Fuller and Kitchin (2004: 10) became "more comfortable" with this line of publishing. If more of us followed this example, not-for-profit publishing could become an aspired norm, challenging corporate academic publishing. Collectively, we can rescript our professional norms and align them with our wider political aims. Unlike priests or soldiers, it is our responsibility as scholars to think beyond the dogmatic conventions that structure our institution (Kant 2005 [1783]). Immanuel Kant would advice us: "Sapere aude! Have courage to use your own reason!"

\section{References}

Association of American Geographers (A.A.G.). 2005. AAG launches study on graduate education in geography. 
www.aag.org/InternalUse/store\%20File/set_templ.cfm?Art-Id=52 . [accessed October 31, 2005]

Becher T. 1989. Academic Tribes and Territories: Intellectual Enquiry and the Culture of Disciplines. Milton Keynes: Open University Press.

Blomley N. 1994. Activism and the academy. Environment and Planning D: Society and Space 12, 383-85.

Bourdieu, P. 1977. Outline of a Theory of Practice. Trans. Richard Rice. Cambridge: Cambridge University Press.

Bourdieu, P. 1988. Homo Academicus. Trans. Peter Collins. Stanford, CA: Stanford University Press.

Bourdieu, P. 2002. Habitus. In, J Hillier \& E Rooksby (eds.), Habitus: Sense of Place. Aldershot, UK: Ashgate, pp. 28-34.

Castree, H. 1999. 'Out there'? 'In here'? Domesticating critical geography. Area 31(1), 81-86.

Castree, N. 2000. Professionalisation, activism, and the university: Whither 'critical geography'? Environment and Planning A 32, 955-970.

Castree, N. and M. Sparke. 2000. Introduction - Professional geography and the corporalization of the university: Experiences, evaluations, and engagements. Antipode 32(3), 222-29.

Castree, N. and M. W. Wright. 2005. Home truths. Antipode 37(2),1-8.

Fuller, D. and R. Kitchin. 2004. Radical theory/critical praxis: academic geography beyond the academy? In, D. Fuller \& R. Kitchin (eds.), Radical Theory/Critical Praxis: Making a difference beyond the academy? Vernon, BC: Praxis (e)Press, pp. 1-20.

Gouldner, A.W. 1979. The Future of Intellectuals and the Rise of the New Class. New York: Seabury Press.

Geography Faculty Development Alliance. 2005. www.colorado.edu/geography/gfda [accessed Oct. 31, 2005].

Halsey, A. H. and M. A. Trow. 1971. The British Academics. London: Faber and Faber. 
Hardwick, S. 2005. Mentoring early career faculty in geography: Issues and strategies. The Professional Geographers 57(1), 21-27.

Johnston, R.J. and J.D. Sidaway. 2004. Geography \& Geographers: Anglo-American Human Geography since 1945. $6^{\text {th }}$ ed. London: Arnold.

Kant, I. 2005 [1783]. Beantwortung der Frage: Was ist Aufkärung? http://gutenberg.spiegel.de [accessed 10 June 2005].

Kuhn, T. S. 1969. The Structure of Scientific Revolution. $2^{\text {nd }}$ ed. Chicago: University of Chicago Press.

Mitchell, D. 2002. Between books and streets, between home, mall and battlefield: The politics and pleasure of Cultural Geography. Antipode 34, 335-39.

Mitchell, K. 1999. Commentary. Environment and Planning A 31, 381-88.

Moss, P., L. D. Berg and C. Desbiens. 2002. The political economy of publishing in Geography. ACME 1(1), 1-7.

Roberts, S. M. 2000. Realizing critical geographies of the university. Antipode 32(3), 230-244.

Said, E. 1994. Representations of the Intellectual. London: Vintage.

Sidaway, J. D. 1997. The production of British geography. Transactions of the Institute of British Geographers 22, 488-504.

Smith, D. M. 2001. On performing geography. Antipode 33, 141-46.

Smith, N. 2000. Afterword: Who rules this sausage factory? Antipode 32(3), 330-39.

Solem, M. N. and K. E. Foote. 2004. Concerns, attitudes, and abilities of early-career geography faculty. Annals of the Association of American Geographers 94(4), 889-912.

Stea, D. 1969. Positions, purposes, pragmatics: A journal of radical geography. Antipode 1(1), 1-2.

Tickell, A. 1995. Reflections on "activism and the academy." Environment and Planning D: Society and Space 13, 235-37.

Ward, K. 2005. Geography and public policy: A recent history of "policy relevance." Progress in Human Geography 29(3), 310-19.

Willis, J. 1996. Laboring for love? A comment on academics and their hours of work. Antipode 28(3), 292-303. 
Willis, P. E. 2004. Foot soldiers of modernity: The dialectics of cultural consumption and the $21^{\text {st }}$-Century school. Harward Educational Review 73(3), 390-415. 